\title{
Soil fauna: key to new carbon models
}

\author{
Juliane Filser ${ }^{1}$, Jack H. Faber ${ }^{2}$, Alexei V. Tiunov ${ }^{3}$, Lijbert Brussaard ${ }^{4}$, Jan Frouz ${ }^{5}$, Gerlinde De Deyn ${ }^{4}$, \\ Alexei V. Uvarov ${ }^{3}$, Matty P. Berg ${ }^{6}$, Patrick Lavelle ${ }^{7}$, Michel Loreau ${ }^{8}$, Diana H. Wall ${ }^{9}$, Pascal Querner ${ }^{10}$, \\ Herman Eijsackers ${ }^{11}$, and Juan José Jiménez ${ }^{12}$ \\ ${ }^{1}$ Center for Environmental Research and Sustainable Technology, University of Bremen, General and \\ Theoretical Ecology, Leobener Str. - UFT, 28359 Bremen, Germany \\ ${ }^{2}$ Wageningen Environmental Research (Alterra), P.O. Box 47, 6700 AA Wageningen, the Netherlands \\ ${ }^{3}$ Laboratory of Soil Zoology, Institute of Ecology \& Evolution, Russian Academy of Sciences, \\ Leninsky prospekt 33, 119071 Moscow, Russia \\ ${ }^{4}$ Dept. of Soil Quality, Wageningen University, P.O. Box 47, 6700 AA Wageningen, the Netherlands \\ ${ }^{5}$ Institute for Environmental Studies, Charles University in Prague, Faculty of Science, Benátská 2, \\ 12843 Praha 2, Czech Republic \\ ${ }^{6}$ Vrije Universiteit Amsterdam, Department of Ecological Science, De Boelelaan 1085, \\ 1081 HV Amsterdam, the Netherlands \\ ${ }^{7}$ Université Pierre et Marie Curie, Centre IRD Ile de France, 32, rue H. Varagnat, 93143 Bondy CEDEX, France \\ ${ }^{8}$ Centre for Biodiversity Theory and Modelling, Station d'Ecologie Théorique et Expérimentale, UMR5321 - \\ CNRS \& Université Paul Sabatier, 2, route du CNRS, 09200 Moulis, France \\ ${ }^{9}$ School of Global Environmental Sustainability \& Dept. Biology, Colorado State University, \\ Fort Collins, CO 80523-1036, USA \\ ${ }^{10}$ University of Natural Resources and Life Sciences, Department of Integrated Biology and Biodiversity \\ Research, Institute of Zoology, Gregor-Mendel-Straße 33, 1180 Vienna, Austria \\ ${ }^{11}$ Wageningen University and Research Centre, P.O. Box 9101, 6700 HB Wageningen, the Netherlands \\ ${ }^{12}$ ARAID, Soil Ecology Unit, Department of Biodiversity Conservation and Ecosystem Restoration, IPE-CSIC, \\ Avda. Llano de la Victoria s/n, 22700 Jaca (Huesca), Spain
}

Correspondence to: Juliane Filser (filser@uni-bremen.de)

Received: 18 March 2016 - Published in SOIL Discuss.: 14 April 2016

Revised: 4 October 2016 - Accepted: 11 October 2016 - Published: 1 November 2016

\begin{abstract}
Soil organic matter (SOM) is key to maintaining soil fertility, mitigating climate change, combatting land degradation, and conserving above- and below-ground biodiversity and associated soil processes and ecosystem services. In order to derive management options for maintaining these essential services provided by soils, policy makers depend on robust, predictive models identifying key drivers of SOM dynamics. Existing SOM models and suggested guidelines for future SOM modelling are defined mostly in terms of plant residue quality and input and microbial decomposition, overlooking the significant regulation provided by soil fauna. The fauna controls almost any aspect of organic matter turnover, foremost by regulating the activity and functional composition of soil microorganisms and their physical-chemical connectivity with soil organic matter. We demonstrate a very strong impact of soil animals on carbon turnover, increasing or decreasing it by several dozen percent, sometimes even turning $\mathrm{C}$ sinks into $\mathrm{C}$ sources or vice versa. This is demonstrated not only for earthworms and other larger invertebrates but also for smaller fauna such as Collembola. We suggest that inclusion of soil animal activities (plant residue consumption and bioturbation altering the formation, depth, hydraulic properties and physical heterogeneity of soils) can fundamentally affect the predictive outcome of SOM models. Understanding direct and indirect impacts of soil fauna on nutrient availability, carbon sequestration, greenhouse gas emissions and plant growth is key to the understanding of SOM dynamics in the context of global carbon cycling models. We argue that explicit consideration of soil fauna is essential to make realistic modelling predictions on SOM dynamics and to detect expected non-linear responses of SOM dynamics to global change. We
\end{abstract}


present a decision framework, to be further developed through the activities of KEYSOM, a European COST Action, for when mechanistic SOM models include soil fauna. The research activities of KEYSOM, such as field experiments and literature reviews, together with dialogue between empiricists and modellers, will inform how this is to be done.

1

Despite continuous refinement over the past decades, estimates of the global carbon cycle still show large discrepancies between potential and observed carbon fluxes (Ballantyne et al., 2012; Schmitz et al., 2014). Soils contain more carbon than the atmosphere and above-ground vegetation together and play an important role for many of the recently adopted UN Sustainable Development Goals. Therefore, soil organic matter (SOM) modelling is key to understanding and predicting changes in global carbon cycling and soil fertility in a changing environment. SOM models can facilitate a better understanding of the factors that underlie the regulation of carbon cycling and the persistence of SOM. The predictive power of current global SOM models is, however, limited, as the majority rely on a relatively restricted set of input parameters such as climate, land use, vegetation, pedological characteristics and microbial biomass (Davidson and Janssens, 2006). Other parameters, such as the leaching of organic matter or soil erosion of organic matter, have been suggested for improving model predictions, and recent research has demonstrated what drastic effects, for example, living roots (Lindén et al., 2014) and soil fungi (Clemmensen et al., 2013) exert on SOM persistence. In an overview of the performance of SOM models, none of 11 tested models could predict global soil carbon accurately, nor were 26 regional models able to assess gross primary productivity across the USA and Canada (Luo et al., 2015).

Some years ago Schmidt et al. (2011) proposed eight "key insights" to enrich model predictions on the persistence of SOM. However, they ignored a major component of SOM dynamics, soil fauna, which plays a fundamental role in most of the insights they propose (e.g. Fox et al., 2006; Jiménez et al., 2006; Osler and Sommerkorn, 2007; De Deyn et al., 2008; Wilkinson et al., 2009). By moving through and reworking soil, feeding on living plant roots, detritus and all types of microorganisms growing on these, soil animals are intimately involved in every step of SOM turnover. Omission of soil fauna from SOM models will, therefore, hamper the potential predictive power of these models.

In a review focusing mostly on large mammals, terrestrial herbivores and aquatic ecosystems, Schmitz et al. (2014) recently called for "animating the carbon cycle". Bardgett et al. (2013) argued that differential responses of various trophic groups of above-ground and below-ground organisms to global change can result in a decoupling of plant-soil interactions, with potentially irreversible consequences for car- bon cycling. A correlative large-scale field study has suggested that including soil animal activities could help clarify discrepancies in existing carbon models (de Vries et al., 2013). Similar attempts to connect animal activity to carbon cycling have occurred in the past (e.g. Lavelle and Martin, 1992; Lavelle et al., 1998; Lavelle and Spain, 2006; Osler and Sommerkorn, 2007; Brussaard et al., 2007; Sanders et al., 2014), without any further change in the structure of carbon models. This was partly due to a lack of communication between modellers and experimenters, but also because the magnitude of animal effects on SOM dynamics remains poorly quantified (Schmitz et al., 2014).

Here we use the "key insights" proposed by Schmidt et al. (2011) as a basis to review current evidence and to identify research needs on the relationship of soil fauna to SOM dynamics. Our review justifies the relevance of incorporating the soil fauna into SOM models. How important animal activities are for manifold geological and pedological processes has been reviewed repeatedly (e.g. Swift et al., 1979; Wilkinson et al., 2009), but carbon turnover - which is highly dynamic and both directly and indirectly affected by animals - had never been the focus. Due to their prime role in most processes in soil (Briones, 2014), we mostly focus on earthworms, but also give examples for other groups of soil fauna whose role in $\mathrm{C}$ turnover appears to be much more relevant than thought thus far (e.g. David, 2014). We point out regional differences in climate, soils and land use with respect to soil fauna composition, abundance and activity and derive implications for SOM modelling. Finally, we introduce a new COST Action (ES 1406) that is working on the implementation of soil fauna into SOM models, also exploring the pros and caveats in such a process.

\section{Key insights}

The eight "key insights" compiled by Schmidt et al. (2011) are shown in Fig. 1, together with the most important activities of soil animals affecting them. As many animal-mediated processes are tightly interconnected, they also matter for most of these insights. For instance, aggregate formation in faeces simultaneously affects molecular structure, humic substances, physical heterogeneity and soil microorganisms. In the following text we briefly summarise the role of animal activities for each of the "key insights". As a more detailed example of animal impacts on SOM turnover, we consider their role on soil aggregate formation in a separate section. 


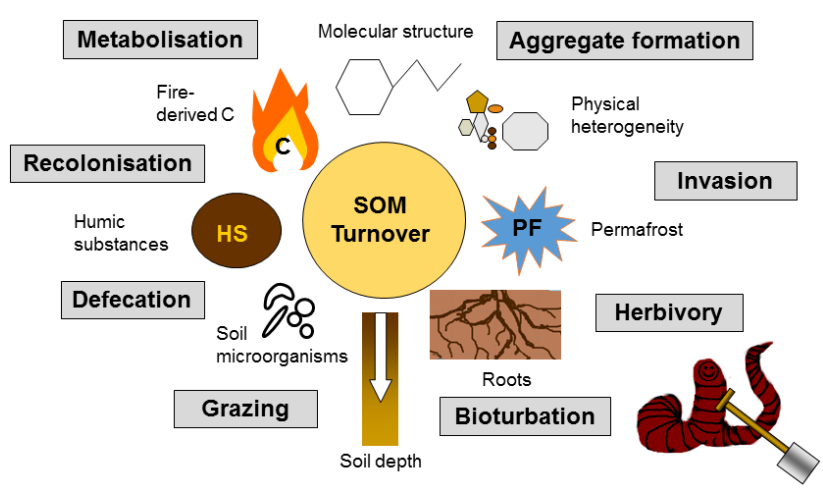

Figure 1. Main animal-mediated processes (boxes) affecting the eight insights (symbols) identified by Schmidt et al. (2011) that should be considered for improving SOM models.

\subsection{Molecular structure}

The molecular structure of root exudates and dead organic matter is modified during metabolisation, decomposition and associated food web transfer, both by microorganisms and soil fauna. Prominent examples are the release of ammonium by bacterivorous protozoans and nematodes, due to their higher $\mathrm{C}: \mathrm{N}$ ratio compared to their bacterial prey (Osler and Sommerkorn, 2007), or the strong mediation of the direction and rate of humus formation by soil animals (see Sect. 2.2). Recently, the significant impact of eight different species of ants over 25 years on mineral dissolution and accumulation of calcium carbonate has even been discussed in the context of geoengineering and carbon sequestration (Dorn, 2014).

Many soil animals ingest and process SOM (and accompanying microorganisms) in their gut system, where it is partly assimilated with the help of mutualistic gut microflora and partly egested. Metabolisation alters the chemical structure of ingested SOM (Jiménez and Lal, 2006; Hedde et al., 2005; Coulis et al., 2009; Frouz et al., 2015b; Schmitz et al., 2014) and, consequently, the decomposition dynamics of animal faeces, which can be a substantial component of SOM (humus). Humification as such renders SOM less decomposable (Blume et al., 2009; Dickinson, 2012), whereas the alkaline milieu in invertebrate midguts accelerates mineralisation (e.g. Li and Brune, 2007).

For instance, earthworm casts have species-specific nearinfrared spectral signatures, indicating presence of specific organic compounds (Hedde et al., 2005). Under grass/legume pasture they are characterised by significant enrichment of slightly altered plant residues in the sand particle size $(>53 \mu \mathrm{m})$. CPMAS 13C NMR (cross-polarisation magicangle spinning carbon-13 nuclear magnetic resonance) spectra showed that earthworm casts and surrounding soil were dominated by carbohydrates, with a decrease in O-alkyl C and an increase in alkyl $\mathrm{C}$ with decreasing particle size (Guggenberger et al., 1996). Moreover, earthworms likely possess a unique capability of neutralising plant polyphenols that otherwise strongly decrease decomposition rates of fresh plant litter (Liebeke et al., 2015). Micro- and mesofauna excrete ammonium or dissolved organic carbon (Filser, 2002; Fox et al., 2006; Osler and Sommerkorn, 2007) and affect the quantity of microbial metabolites (Bonkowski et al., 2009). Gut passage, defecation, and excretion, together with bioturbation by macro- and mesofauna, facilitate humification and decomposition, also altering nutrient stoichiometry (Bohlen et al., 2004). These modifications in the molecular structure of SOM due to soil fauna activity have significant effects on its dynamics (Swift et al., 1979; Guggenberger et al., 1995; Blume et al., 2009; Dickinson, 2012; and other references related to points 1 and 2 in Table 1 ).

\subsection{Humic substances}

As stated above, humification increases SOM stability. The term "humic substances" (here defined as very large and highly complex, poorly degradable organic molecules with manifold aromatic rings; Lehmann and Kleber, 2015) may be considered problematic by part of the scientific community: neither is the concept itself clear, nor is there any evidence that the often mentioned highly complex large organic molecules play any relevant role in organic matter stabilisation under natural conditions (Schmidt et al., 2011; Lehmann and Kleber, 2015). However, here we stick to it when referring to the "insights", simply for reasons of consistency with the article our argumentation is based on Schmidt et al. (2011). We acknowledge that "humus" or "humic substances" represent a continuum of more or less decomposed dead organic matter of which energy content and molecule size mostly should decrease over time, and that water solubility, sorption to the mineral matrix and accessibility for microorganisms are highly relevant for OM turnover (Lehmann and Kleber, 2015).

Humic substances are formed during the gut passage: organic matter in young soils and humic horizons almost completely consists of soil animal faeces (Lavelle, 1988; Martin and Marinissen, 1993; Brussaard and Juma, 1996). Humus forms mainly comprise animal casts, e.g. casts of ants, isopods, millipedes, beetle larvae or termites in deadwood; casts of insect larvae and spiders in leaf litter; or casts of collembolans, mites and enchytraeids in raw humus. In his review, David (2014) considered macroarthropod casts being a factor of partial SOM stabilisation, rather than hotspots of microbial activity. The dark colour of casts (compared to the ingested organic material) visually demonstrates the strong chemical OM modification in animal guts, which is accompanied by a substantial physical modification. Clay-humus complexes, physically protecting organic matter (Jiménez and Lal, 2006), are mainly faeces of earthworms and diplopods (see also Sect. 2.5 on physical heterogeneity). Due to differences in feeding preferences, gut microflora, SOM quantities consumed, etc. of soil animals, their faeces vary in size, shape and quality not only between 
Table 1. Quantitative examples of the impact of earthworms and selected groups of other soil fauna on soil properties and processes involved in soil organic matter (SOM) turnover. If not mentioned otherwise, any numbers or percentages refer to the control without fauna. Selected, particularly striking examples are printed in bold.

\begin{tabular}{|c|c|c|}
\hline Insight* & Examples & Source \\
\hline \multicolumn{3}{|c|}{ Earthworms } \\
\hline \multirow[t]{2}{*}{$\begin{array}{l}\text { 2. Humic } \\
\text { substances }\end{array}$} & $\begin{array}{l}\text { An indicator of lignin degradation in earthworm casts was twice that } \\
\text { of the surrounding soil. } \\
\text { Introduced earthworms can double microaggregate formation and the } \\
\text { stabilisation of new } \mathrm{C} \text { in the topsoil. }\end{array}$ & $\begin{array}{l}\text { Guggenberger et al. } \\
\text { (1995) } \\
\text { Marashi and } \\
\text { Scullion (2003), } \\
\text { Six et al. (2004) }\end{array}$ \\
\hline & $\begin{array}{l}\text { C protection is promoted by microaggregates within large } \\
\text { macroaggregates, and earthworms can add } 22 \% \text { anew to this } \mathrm{C} \text { pool } \\
\text { Exclusion of earthworms reduced SOC accumulation by } 0 \text { (at } 0-10 \mathrm{~cm} \\
\text { depth) to } 75 \% \text { (at } 30-40 \mathrm{~cm} \text { depth), associated with a decrease in } \\
\text { percentage of water-stable aggregates. } \\
\text { In organic layers of a Canadian aspen forest, in locations with } \\
\text { earthworms, } \mathrm{N}(1.5-0.8 \% \text { ) and especially C concentrations }(25.3- \\
9.8 \% \text { ) were strongly reduced, together with C / N ratio (16.7-13.2) and } \\
\text { soil pH (6.5-6.1); in brackets: control values vs. values with } \\
\text { earthworms. This suggests a shift towards a faster cycling system, } \\
\text { resulting in a net loss of C from the soil and turning northern } \\
\text { temperate forests from C sinks into C sources. }\end{array}$ & $\begin{array}{l}\text { Albrecht et al. (2004), } \\
\text { cited in Schmidt et } \\
\text { al. (2011) } \\
\text { Eisenhauer et al. } \\
\text { (2007) }\end{array}$ \\
\hline $\begin{array}{l}\text { 3. Fire-derived } \\
\text { carbon }\end{array}$ & $\begin{array}{l}\text { Small charcoal particles from burned plots after } 1 \text { year increased by } \\
21 \% \text { at } 0-1 \mathrm{~cm} \text { depth. One year later they were concentrated in } \\
\text { earthworm casts at the soil surface, after } 6.5 \text { years such casts were } \\
\text { found at } 8 \mathrm{~cm} \text { depth. }\end{array}$ & $\begin{array}{l}\text { Eckmeier et al. } \\
\text { (2007) }\end{array}$ \\
\hline 4. Roots & $\begin{array}{l}\text { Presence of earthworms in a continuous maize plot in Peruvian } \\
\text { Amazonia increased the organic } \mathrm{C} \text { input from roots by } 50 \% \text {. }\end{array}$ & Jiménez and Lal (2006) \\
\hline \multirow{6}{*}{$\begin{array}{l}\text { 5. Physical } \\
\text { heterogeneity } \\
\text { (see also insights } \\
\text { no. } 2,3,6 \text { and } 7 \text { ) }\end{array}$} & $\begin{array}{l}\text { Up to } 50 \% \text { of soil aggregates in the surface layer of temperate } \\
\text { pastures are earthworm casts. }\end{array}$ & $\begin{array}{l}\text { van de Westeringh } \\
(1972)\end{array}$ \\
\hline & $\begin{array}{l}\text { Mull-type forest soil top layers and wooded savanna soils consist } \\
\text { almost entirely of earthworm casts. }\end{array}$ & $\begin{array}{l}\text { Kubiena (1953), } \\
\text { Lavelle (1978) }\end{array}$ \\
\hline & $\begin{array}{l}\text { Earthworm inoculation in pastures on young polder soils } \\
\text { completely removed the organic surface layer within 8-10 years and } \\
\text { incorporated it into deeper layers, creating an A horizon. This } \\
\text { affected manifold measures, increasing, for example, grass yield by } 10 \% \text {, } \\
\text { root content in } 0-15 \% \text { from } 0.38 \text { to } 1.31 \mathrm{~g} \mathrm{dm}^{-3} \text {, C content at } 0-20 \\
\text { cm from } 1.78 \text { to } 16.9 \mathrm{~kg} \mathrm{C} \cdot 10^{3} \mathrm{ha}^{-1} \text {, and water infiltration } \\
\text { capacity from } 0.039 \text { to } 4.6 \mathrm{~m} 24 \mathrm{~h}^{-1} \text {. In turn, penetration resistance } \\
\text { at } 15 \mathrm{~cm} \text { depth decreased from } 35 \text { to } 22 \mathrm{~kg} \mathrm{~cm}^{-2} \text {. }\end{array}$ & $\begin{array}{l}\text { Hoogerkamp et al. } \\
\text { (1983) }\end{array}$ \\
\hline & $\begin{array}{l}\text { In average temperature pasture and grasslands, earthworms cast } 40-50 \\
\mathrm{tha}^{-1} \mathrm{yr}^{-1} \text { on the surface and even more below surface. }\end{array}$ & Lee (1985) \\
\hline & $\begin{array}{l}\text { Passage of a tropical soil through the gut of the invading } \\
\text { earthworm Pontoscolex corethrurus reduced macroporosity from } \\
21.7 \text { to } 1.6 \mathrm{~cm}^{3} \mathrm{~g}^{-1} \text {, which exceeded the effect of mechanically } \\
\text { compacting the same soil at } 10^{3} \mathrm{kPa} \text { (resulting macroporosity: } \\
3 \mathrm{~cm}^{3} \mathrm{~g}^{-1} \text { ). }\end{array}$ & $\begin{array}{l}\text { Wilkinson et al. } \\
\text { (2009) }\end{array}$ \\
\hline & $\begin{array}{l}\text { After invasion of European earthworms into a Canadian aspen forest a } \\
\text { thick layer of their cast material (thickness up to } 4 \mathrm{~cm} \text { ) on top of } \\
\text { organic layers was developed. }\end{array}$ & $\begin{array}{l}\text { Eisenhauer et al. } \\
(2007)\end{array}$ \\
\hline 6. Soil depth & $\begin{array}{l}\text { Burrows of anecic earthworms are up to several metres deep and last } \\
\text { for many years. }\end{array}$ & $\begin{array}{l}\text { Edwards and } \\
\text { Bohlen (1996) }\end{array}$ \\
\hline $\begin{array}{l}\text { 7. Permafrost } \\
\text { and boreal areas }\end{array}$ & $\begin{array}{l}\text { Earthworm invasions in boreal forests completely transformed mor to } \\
\text { mull soils and significantly altered the entire plant community. }\end{array}$ & $\begin{array}{l}\text { Frelich et al. } \\
\text { (2006) }\end{array}$ \\
\hline $\begin{array}{l}\text { 8. Soil } \\
\text { microorganisms }\end{array}$ & $\begin{array}{l}\text { Earthworms may lower actual microbial activity (by } 11-23 \% \text { ) but markedly } \\
\text { (by } 13-19 \% \text { ) optimise microbial resource utilisation. }\end{array}$ & $\begin{array}{l}\text { Scheu et al. } \\
(2002)\end{array}$ \\
\hline
\end{tabular}


Table 1. Continued.

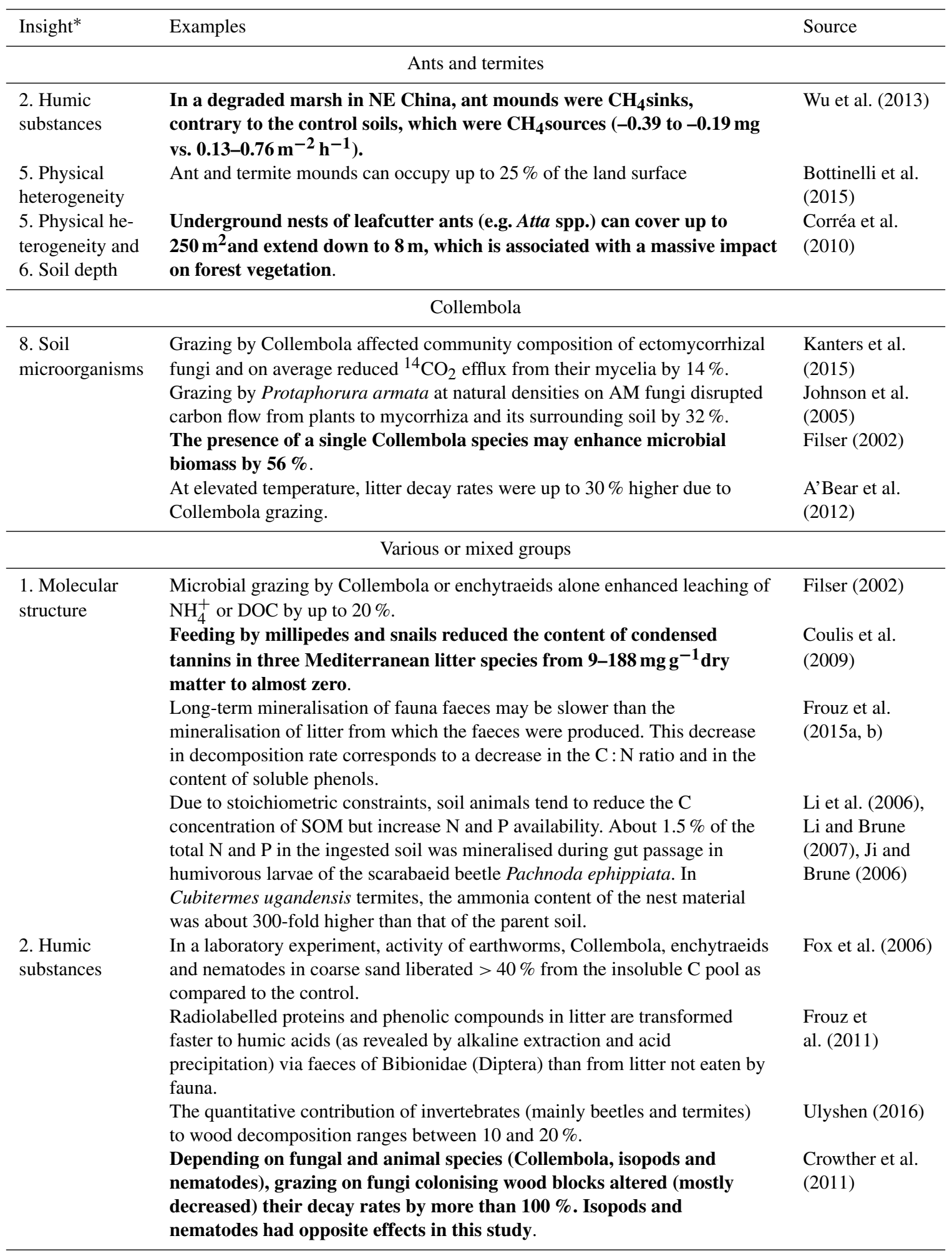


Table 1. Continued.

\begin{tabular}{|c|c|c|}
\hline Insight* & Examples & Source \\
\hline \multicolumn{3}{|c|}{ Various or mixed groups } \\
\hline $\begin{array}{l}\text { 2. Humic } \\
\text { substances } \\
\text { (continued) }\end{array}$ & $\begin{array}{l}\text { Carbon and nitrogen losses from soil followed by drought and rewetting } \\
\text { were substantially affected by microarthropod richness, which explained } \\
42 \% \text { of the residual variance. }\end{array}$ & $\begin{array}{l}\text { de Vries et al. } \\
\text { (2012) }\end{array}$ \\
\hline $\begin{array}{l}\text { 5. Physical } \\
\text { heterogeneity }\end{array}$ & $\begin{array}{l}\text { Bioturbation rates of soil animal groups typically range between } \\
1 \text { and } 5 \mathrm{Mgha}^{-1} \mathrm{yr}^{-1} \text { but may reach up to } 10 \text { (crayfish, termites), } \\
20 \text { (vertebrates), } 50 \text { (earthworms) and }>100 \mathrm{Mgha}^{-1} \mathrm{yr}^{-1} \text { (earthworms in } \\
\text { some tropical sites), which is equivalent to maximum rates of tectonic } \\
\text { uplift. }\end{array}$ & $\begin{array}{l}\text { Wilkinson et al. } \\
\text { (2009) }\end{array}$ \\
\hline \multirow[t]{2}{*}{$\begin{array}{l}\text { 8. Soil } \\
\text { microorganisms }\end{array}$} & $\begin{array}{l}\text { In the course of a } 2.5 \text {-year succession, fauna activities (especially of } \\
\text { nematodes and mesofauna during the first year, and later of earthworms) } \\
\text { accelerated microbial decomposition of clover remains in an arable soil } \\
\text { by } 43 \% \text {. }\end{array}$ & Uvarov (1987) \\
\hline & $\begin{array}{l}\text { Depending on vegetation, animal group and climate, soil animals directly } \\
\text { or indirectly increased } \mathrm{C} \text { mineralisation between } 1 \text { and } 32 \% \text {. However, } \\
\text { intensive grazing by fungal feeders may even reduce } \mathrm{C} \text { mineralisation. }\end{array}$ & Persson (1989) \\
\hline
\end{tabular}

fauna groups but also between species within one group (see Sect. 3 on aggregate formation). Discovering the important role of animal faeces in humification is essential to improve our understanding of carbon dynamics in soil.

\subsection{Fire-derived carbon}

Fire-derived carbon is chemically highly condensed and thus often hardly degradable. However, its stability in soil is variable and still poorly understood (Schmidt et al., 2011; Wang et al., 2016). Two of the factors identified by a meta-analysis on the stability of biochar in soil were association with aggregates and translocation in the soil profile (Wang et al., 2016), which are both strongly affected by soil fauna (see Sects. 2.5, 2.6 and 3). Microbial recolonisation of burned sites is mediated by wind and soil animals that survived in soil or emigrated from neighbouring areas, e.g. by macroand mesofauna, birds and mice (Malmström, 2012; Zaitsev et al., 2014). Moreover, soil fauna also ingest the charcoal particles (Eckmeier et al., 2007; see Table 1). Due to animal activity, charcoal is sorted by size and translocated down the soil profile. Mice and earthworms (Eckmeier et al., 2007) and the tropical earthworm Pontoscolex corethrurus (Topoliantz and Ponge, 2003; Topoliantz et al., 2006) had been suggested as responsible for rapid incorporation of charcoal into the soil. Quantitative data are, however, scarce (Table 1). In spite of potentially great importance, the effect of soil animals on the fate of the "black carbon" in soil remains practically unknown (Ameloot et al., 2013).

\subsection{Roots}

Roots not only represent a major input pathway of carbon into soil, but together with associated microflora they also have a large influence on the turnover dynamics of existing soil carbon (Finzi et al., 2015). Roots preferably grow in existing soil cavities (Jiménez and Lal, 2006), mostly formed by soil fauna (Wilkinson et al., 2009). Both burrowing and non-burrowing soil animals have a strong impact on root growth, allocation, length and density (Brown et al., 1994; Bonkowski et al., 2009; Arnone and Zaller, 2014). Animal grazing of root bacteria and mycorrhiza affects their activity and community composition, and animal excreta are enriched in micronutrients and selectively affect plant nutrition (Brown, 1995; Filser, 2002; Brussaard et al., 2007). Root herbivores and rhizosphere grazers affect $\mathrm{C}$ allocation of roots (Wardle et al., 2004) and largely regulate nutrient acquisition and plant productivity (Bonkowski et al., 2009). Not only root herbivores but also saprotrophic/microbivorous soil animals may obtain a significant proportion of energy from plant roots (Pollierer et al., 2007). This suggests an animalmediated regulatory loop that connects plant roots and SOM.

\subsection{Physical heterogeneity}

Schmidt et al. (2011) considered the physical disconnection between decomposers and organic matter to be one reason for SOM persistence in deep soil. However, physical heterogeneity in soils occurs at all spatial scales, and animals play a fundamental role in the distribution of organic matter and associated microorganisms. According to body size, decomposers act at various spatial scales, from micro-aggregates to landscapes (Ettema and Wardle, 2002; 
Jouquet et al., 2006). They fragment organic residues, perform bioturbation, distribute dead organic matter and generate smaller and larger organic matter hotspots (e.g. faecal pellets, ant and termite mounds). Mounds and burrows are obvious signs of physical heterogeneity created by ecosystem engineers (Meysmann et al., 2006; Wilkinson et al., 2009; Sanders et al., 2014). These structures significantly affect microorganisms and plants (Chauvel et al., 1999; Frelich et al., 2006) and associated soil properties such as aggregate stability (Bossuyt et al., 2005, 2006) and hydraulic properties (Bottinelli et al., 2015; Andriuzzi et al., 2015). This has consequences for the sorption and degradation (Edwards et al., 1992; Bolduan and Zehe, 2006) and for C emissions (Wu et al., 2013; Lopes de Gerenyu et al., 2015). Earthworms in particular feed on organic and mineral parts of the soil and mix them (Eckmeier et al., 2007; Wilkinson et al., 2009). The resulting clay-organic matter complexes considerably increase SOM retention of soils (Jiménez and Lal, 2006; Fox et al., 2006; Brussaard et al., 2007), although C loss from fresh casts is much higher than from surrounding soil (Zangerlé et al., 2014). The impact on soil processes and physical heterogeneity varies considerably between different groups of ecosystem engineers (Jouquet et al., 2006; Bottinelli et al., 2015). For instance, some earthworm species strongly affect their physical environment, while others are more linked to the soil organic matter content (Jiménez et al., 2012).

\subsection{Soil depth}

In most soil types, pore volume, carbon content, associated biotic processes and temperature variability strongly decrease with depth, whereas other parameters such as bulk density and water content increase - all of which significantly affect SOM turnover rates. The depth of organic horizons varies with soil type, from almost zero to several metres. Thus, Schmidt et al. (2011) identified soil depth as another "key insight". Nevertheless, digging animals play a key role in the development of soil depth. Animal burrows, which can reach several metres deep, are a considerable part of physical heterogeneity. Bioturbation (e.g. by earthworms, termites, ants, beetle and Diptera larvae, spiders, solitary bees and wasps, snails, isopods and amphipods, puffins, lizards, porcupines, pigs, moles, voles, rabbits, foxes, or badgers) is a key process to the formation of soil depth, soil structure and associated $\mathrm{C}$ translocation, as shown by several examples in Table 1 and reviewed, for example, by Wilkinson et al. (2009).

\subsection{Permafrost}

In permafrost soil up to $1672 \times 10^{15} \mathrm{~g}$ carbon is stored (Tarnocai et al., 2009). Organism activity is mostly restricted to the short periods of time when the upper centimetres of the soil are thawed. Due to unfavourable environmental conditions (resulting in low animal biomass, activity and diver- sity), there is only a minor impact of fauna in permafrost soils (De Deyn et al., 2008). However, fauna invasions, especially of the above-mentioned soil engineers, due to soil melting in tundra and boreal forests are likely to have drastic effects (Frelich et al., 2006; van Geffen et al., 2011). Data on earthworm invasions in North American forests (Bohlen et al., 2004; Frelich et al., 2006; Eisenhauer et al., 2007) show that they must be taken into consideration in carbon-rich soils, particularly in melting permafrost soils (Frelich et al., 2006; Schmidt et al., 2011), where they may affect many soil functions.

\subsection{Soil microorganisms}

After roots, microorganisms constitute by far the largest share of biomass in soil biota. Accordingly, they have a crucial role in SOM turnover. They consume root exudates and dead organic matter, attack plants and animals as pathogens, or support them as mutualists. Finally, microorganisms are the most important food source for the majority of soil animals, and also to a considerable extent for above-ground insects and vertebrates. Soil fauna comprises ecosystem engineers as well as an armada of mobile actors connecting elements of the soil system, thus mediating microbial processes (Briones, 2014). Countless isopods, ants, termites, enchytraeids, microarthropods, nematodes or protozoans make large contributions to SOM turnover underground (Persson, 1989; Filser, 2002; Wardle et al., 2004; Fox et al., 2006; Osler and Sommerkorn, 2007; Wilkinson et al., 2009; Wu et al., 2013). They affect the activity and community composition of soil microorganisms in multiple ways such as feeding and burrowing, facilitating the coexistence of different fungal species (Crowther et al., 2011) or by modifying micro-habitat conditions. Litter comminution by detritivores increases SOM accessibility for microorganisms, and propagules are dispersed with body surface and casts. The gut environment provides protected microsites with modified biotic and abiotic conditions, which increase bacterial abundance substantially - e.g. by three orders of magnitude in earthworm guts (Edwards and Fletcher, 1988). Grazing affects microbial biomass, activity and community composition, and animal excreta modify nutrient availability for microorganisms (Brown, 1995; Filser, 2002).

Table 1 contains quantitative examples of animal activity taken from different biomes and land-use types, showing that earthworms alone strongly affect each of the "key insights". However, much smaller soil animals can also have substantial effects (Table 1). It has to be kept in mind that the separation of animals' effects according to the insights is somewhat arbitrary as the associated soil processes are often interconnected. This is particularly obvious for molecular structure, humic substances, roots, physical heterogeneity, soil depth and microorganisms: metabolisation implies by definition an alteration of the molecular structure, often associated with the formation of humic substances. The stability of the latter 
has a very strong association with physical protection, and whether metabolisation of dead organic matter occurs at all depends on its horizontal and vertical distribution. For instance, earthworms will (a) translocate dead organic matter both vertically and horizontally; (b) transform part of it via metabolisation; (c) mix ingested OM with minerals, thus affecting its physical protection; (d) increase and alter the microbial community; and (e) affect hydraulic properties and aeration of the soil through digging and tunnelling, which has an immediate impact on the activity of microorganisms and on root growth.

As this example illustrated only the most important aspects of interacting processes, the next section provides a more elaborate overview of aggregate formation.

\section{Aggregate formation}

The modern view on the stability of organic matter in soils requires a thorough understanding of aggregate structure and formation, including the role of soil biota (Lehmann and Kleber, 2015). Soil aggregation is the process by which aggregates of different sizes are joined and held together by different organic and inorganic materials. Thus, it includes the processes of formation and stabilisation that occur more or less continuously and can act at the same time. With clay flocculation being a prerequisite for soil aggregation, the formation of aggregates mainly occurs as a result of physical forces, while their stabilisation results from a number of factors, depending in particular on the quantity and quality of inorganic and organic stabilising agents (Amézketa, 1999).

By bioturbation, feeding and dispersal of microbial propagules soil animals regulate all of the above forces and agents and are therefore a crucial factor in the formation and stabilisation of soil aggregates. Earthworms, many insect larvae and other larger fauna may stabilise aggregate structure by ingesting soil and mixing it intimately with humified organic materials in their guts and then egesting it as casts or pellets (Tisdall and Oades, 1982; Oades, 1993).

Earthworms have a direct and fast impact on microaggregate formation and the stabilisation of new $\mathrm{C}$ within these microaggregates (Bossuyt et al., 2005) (Table 1). There are several mechanisms to explain the increase in micro- and macroaggregate stability by earthworms, but no mechanism has been quantified in relation to population size yet. Effects are related to ecological groups of earthworms, associated with feeding habit, microhabitat in the soil profile, and burrow morphology. However, irrespective of this classification, species may enhance or mitigate soil compaction (Blanchart et al., 1997; Guéi et al., 2012). The tensile strength of casts (roughly defined as the force required to crush dried aggregates, i.e. an indirect measure of physical SOM protection) appears to be species-dependent: for example, the casts of Dendrobaena octaedra have a lower tensile strength compared to those of L. terrestris (Flegel et al., 1998). Simi- larly, organic carbon and water-stable aggregation was significantly higher in casts of $L$. terrestris than in casts of A. caliginosa (Schrader and Zhang, 1997).

Some research, however, suggests that earthworm activity can also evoke soil degradation. Shipitalo and Protz (1988) proposed that ingestion of soil by earthworms results in disruption of some existing bonds within micro-aggregates and realignment of clay domains. Therefore, fresh casts are more dispersible than uningested soil, contributing to soil erosion and crusting. Significant improvement in the water stability of fresh, moist casts only occurs when incorporated organic debris from the food sources is present and when moist casts are aged or dried. Nevertheless, in the long term, casting activity enhances soil aggregate stability.

However, our understanding of the contribution of soil fauna to aggregate formation and stabilisation is limited, and mostly qualitative in nature. Different methodologies complicate the comparison among aggregate stability data (Amézketa, 1999). Data in terms of functional response to density are limited as many studies have been conducted in arable systems, where the diversity and abundance of soil animals are reduced as a consequence of tillage, mineral fertilisers and pesticide use. Recently, some studies on these topics have emerged. A negative correlation between earthworm abundance and total macroaggregates and microaggregates within macroaggregates in arable treatments without organic amendments could be linked to the presence of high numbers of Nematogenia lacuum, an endogeic species that feeds on excrements of other larger epigeic worms and produces small excrements (Ayuke et al., 2011). Under the conditions studied, differences in earthworm abundance, biomass and diversity were more important drivers of management-induced changes in aggregate stability and soil $\mathrm{C}$ and $\mathrm{N}$ pools than differences in termite populations. Another study highlighted that in fields converted to notillage management, earthworms incorporated $\mathrm{C}$ recently fixed by plants and moved $\mathrm{C}$ from soil fragments and plant residues to soil aggregates of $>1 \mathrm{~mm}$ (Arai et al., 2013). Thus, soil management practices altering fauna activities may have a significant effect on the redistribution of soil organic matter in water-stable aggregates, impacting agronomically favourable size fractions of water-stable macroaggregates, and water-stable micro-aggregates, which are the most important source of carbon sequestration (Šimanský and Kováčik, 2014).

\section{Regional differences in climate, soils and land use}

In a global meta-analysis spanning several continents, García-Palacios et al. (2013) show that, across biomes and scales, the presence of soil fauna contributes on average $27 \%$ to litter decomposition. Depending on the situation, this contribution can be substantially lower or higher. For instance, the authors report an average increase in decomposi- 


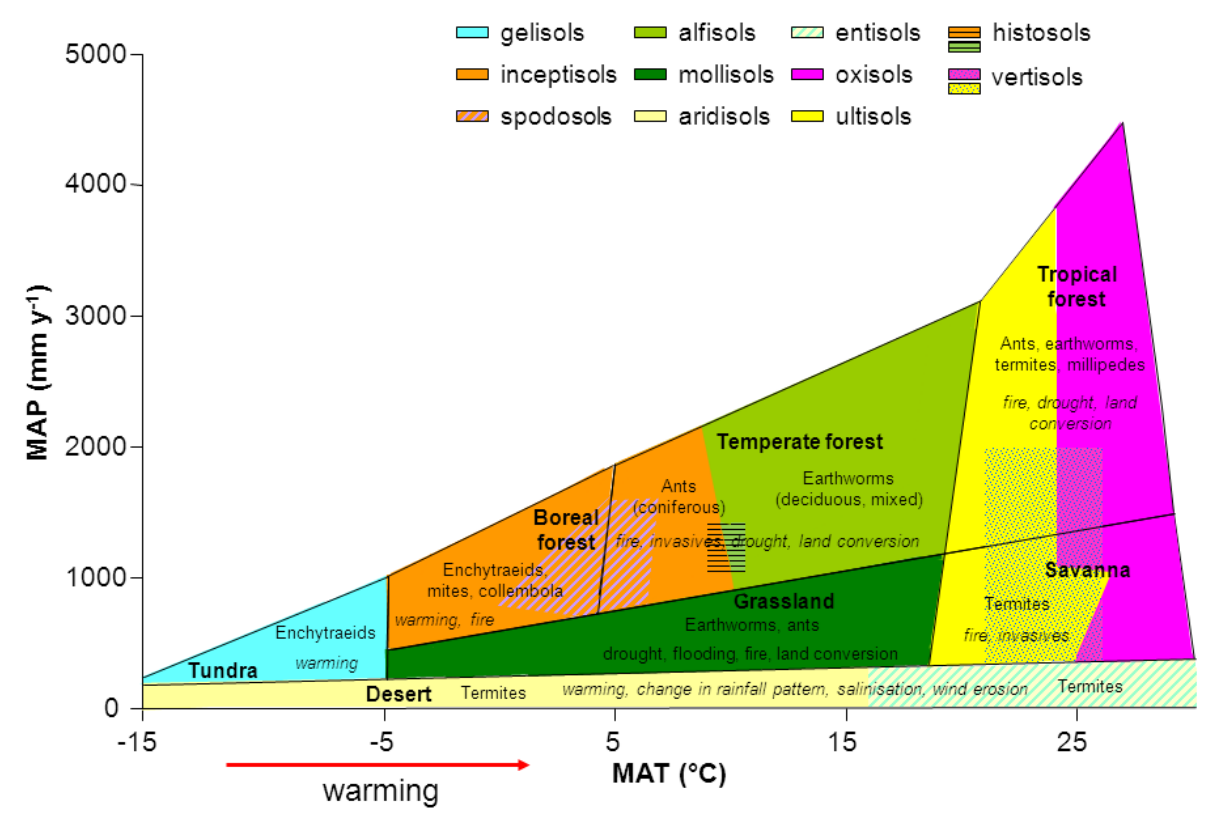

Figure 2. Dominant soil types and characteristic soil forming invertebrates across biomes (major global change threats are shown in italics). MAT: mean annual temperature; MAP: mean annual precipitation. For data and biome sources, see Brussaard et al. (2012). ${ }^{\odot}$ John Wiley and Sons. Reprint (slightly modified) by kind permission from John Wiley and Sons and Oxford University Press.

tion rates of $47 \%$ in humid grasslands, whereas in coniferous forests this figure amounts to only $13 \%$. The high impact of soil fauna in humid grasslands is all the more important as such grasslands are among those ecosystems that are most severely affected by global environmental change (Chmura et al., 2003; Davidson and Janssens, 2006).

Many of our examples refer to earthworms and temperate regions as they have been studied most intensively. However, we suggest that any dominant group of soil fauna, irrespective of body size or the ability to create larger soil structures, may substantially affect carbon dynamics. Table 1 gives a number of respective case studies. The key players and specific effects of soil animals vary across space (Fig. 2), with increasing importance for SOM dynamics in humid-warm and nutrient-limited conditions (Persson, 1989; Filser, 2002; Wardle et al., 2004; Fox et al., 2006; Osler and Sommerkorn, 2007; De Deyn et al., 2008; Briones, 2014). Once key players in a given ecosystem have been identified as relevant for being included in SOM models (see Sect. 6 and Fig. 3), more detailed information on their biology is required, in particular on their activity, ecological niche and corresponding tolerance limits. All this varies with species, and often extremely within one systematic group. Variation in drought or soil temperature towards limiting conditions will first increase (stress response, e.g. downward migration) and then strongly decrease activity (mortality or transition to inactive resting stage). Some key players will exhibit high abundance and be extremely active throughout the year (Wilkinson et al., 2009), while others might only be moderately relevant dur- ing a short period of time; the contribution of a third group might be considered insignificant.

Ecosystem engineers also differ between soil types, biomes and land-use types, from rodents and ants in dry areas to termites, earthworms and millipedes in tropical rainforests. They consume different types of organic matter, make deep or shallow, narrow or wide burrows, and differ in aggregation behaviour (e.g. more or less regularly distributed earthworms versus distinct ant nests and termite mounds). Accordingly, their role in SOM redistribution and turnover differs as well.

In cold ecosystems - where, together with wetlands and peatlands, the majority of terrestrial carbon is stored (Davidson and Janssens, 2006) - the response of detritivores to climatic change is expected to be most pronounced (Blankinship et al., 2011). Melting of permafrost soil might lead to northward expansion of soil macro-invertebrates, associated with accelerated decomposition rates (van Geffen et al., 2011). Further examples are shown in Table 1.

More information is needed on how existing abiotic and biotic constraints to SOM decomposition will vary with changing climate and in different regions (Davidson and Janssens, 2006). Finally, human activity comes into play: any significant land use change, particularly soil sealing and conversion of native forest to agricultural land, has dramatic consequences for abundances and species composition of soil communities. The same holds true for management intensity and pollution (Filser et al., 1995, 2002; Filser and Prasse, 2008; de Vries et al., 2012). However, even seemingly harmless activities can be significant, as we will show for the case 
(a) Soil Fauna

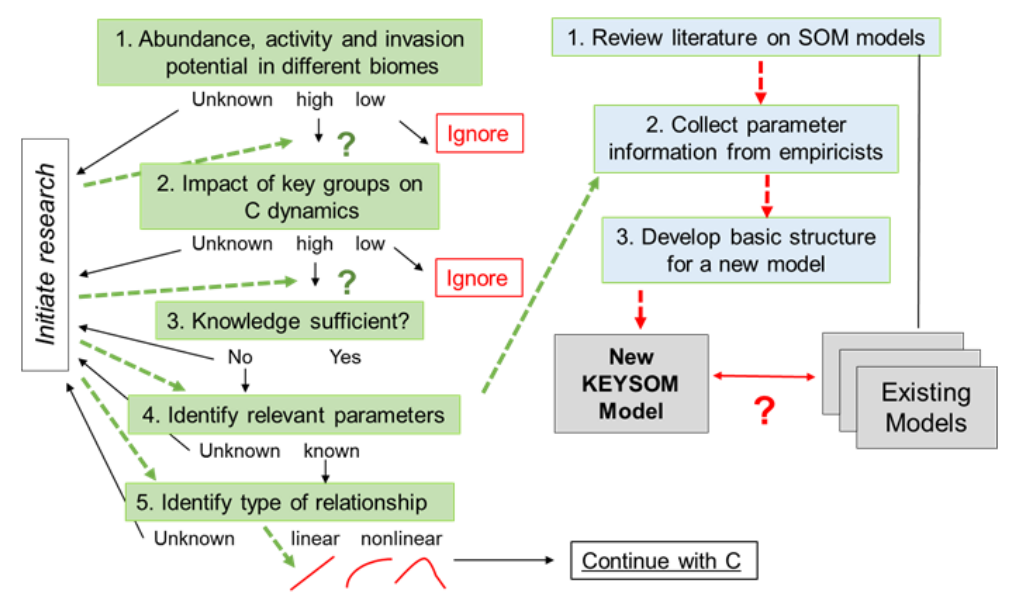

(c) Model Synthesis

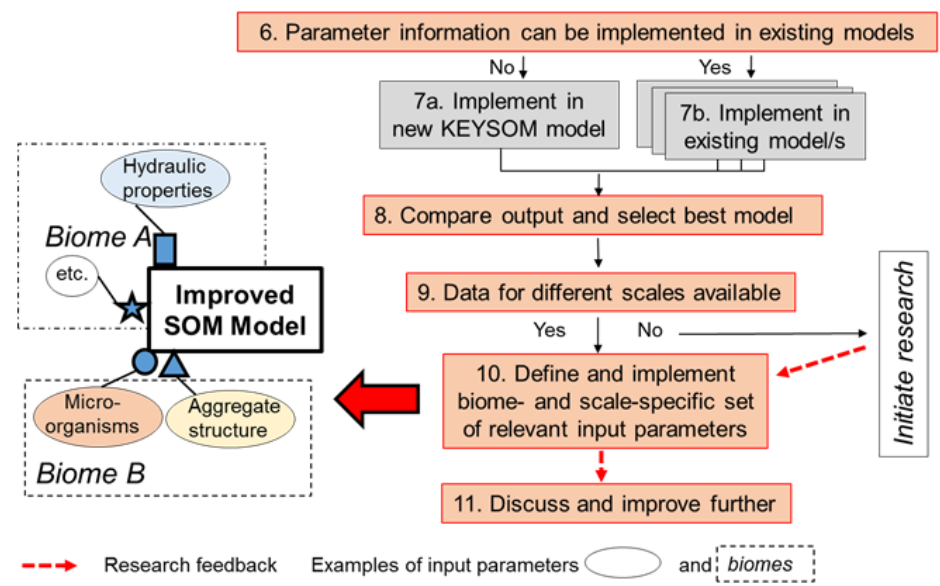

Figure 3. Flow scheme for an improved understanding of the role of soil fauna for soil organic matter (SOM) turnover. This scheme is basically followed within the COST Action ES 1406 (KEYSOM). Activities in (a) and (b) run parallel, followed by (c), which ends with an improved SOM model. Example scenarios are shown for two biomes. For further explanations, see text.

of fishing at the end of Sect. 5 - pointing out the relevance of human activities for soil fauna beyond impact on global warming and land use change. How we address all this biogeographical and ecological variation is shown in Sects. 5 and 6.

\section{Implications for modelling}

As there is no unambiguous scientific support for the widespread belief in "humic substances", the question of how long organic carbon remains in soil is largely related to (a) physical protection and (b) how often the once photosynthesised dead organic matter is recycled in the soil food web. For both processes soil animals are of great importance, as we have shown above. Biomass and abundance of soil animals are generally constrained by temperature, humidity and food (living or dead organic matter). However, the effects of these constraints on their activity are not simply additive, nor is there any simple relation between biomass and activity. For example, despite overall unfavourable conditions for the majority of soil organisms, burrowing activity in deserts can be extremely high (Filser and Prasse, 2008). Moreover, there is increasing evidence that fauna effects on energy and nutrient flow can be at least partly decoupled from other abiotic and biotic factors (Frouz et al., 2013). De Vries et al. (2013) even concluded that "soil food web properties strongly and consistently predicted processes of $\mathrm{C}$ and $\mathrm{N}$ cycling across land use systems and geographic locations, and they were a better predictor of these processes than land use". This implies that knowledge of fauna may increase our prediction power. The thermodynamic viewpoint makes the issue even more relevant: reaction speed increases with temperature, but most soil organisms are rather adapted to relatively cool conditions and might thus be pushed beyond their niche limits with eventually negative consequences on their activity (see Sect. 4). 
Table 2. "Insights" (compiled after Schmidt et al., 2011) for future soil organic matter models and recommendations for further improvements by implementing effects of soil fauna.

\begin{tabular}{|c|c|}
\hline $\begin{array}{l}\text { SOM modelling } \\
\text { element ("insight") }\end{array}$ & Recommendations* \\
\hline 1. Molecular structure & $\begin{array}{l}\text { Incorporate the knowledge on the structure of organic substances and element concentrations } \\
\text { in faunal casts and excreta in SOM decay rate models. Consider linkage between } \mathrm{C} \text { and } \mathrm{N} \\
\text { cycling mediated by fauna. See } 8 \text {. }\end{array}$ \\
\hline 2. Humic substances & $\begin{array}{l}\text { Add physical and chemical stability of casts, patterns of their microbial colonisation and } \\
\text { degradation dynamics. See } 1,3,5,6,7,8 \text {. }\end{array}$ \\
\hline 3. Fire-derived carbon & $\begin{array}{l}\text { Include recolonisation and inoculation potential of surviving soil fauna and adjacent fauna. } \\
\text { Initiate studies on the impact of fauna on the fate of black carbon (fragmentation, gut, casts, } \\
\text { decomposition, and recolonisation). }\end{array}$ \\
\hline 4. Roots & Add activity of bioturbators, rhizosphere microbial grazers and root herbivores. See $1,5,6,8$. \\
\hline $\begin{array}{l}\text { 5. Physical } \\
\text { heterogeneity }\end{array}$ & $\begin{array}{l}\text { Consider spatial and physicochemical heterogeneity created by soil fauna, including } \\
\text { consequences of soil aggregation and dis-aggregation (e.g. bulk density, infiltration rate, } \\
\text { preferential flow, casts). See } 1,2,6,8 \text {. }\end{array}$ \\
\hline 6. Soil depth & $\begin{array}{l}\text { Incorporate burrowing depth and annual transport rates of bioturbators and animal-induced } \\
\text { spatial heterogeneity of old and young carbon in the deep soil. See } 5 \text {. }\end{array}$ \\
\hline 7. Permafrost & $\begin{array}{l}\text { For warming scenarios, take into account short- and long-term invasion effects, particularly of } \\
\text { earthworms and enchytraeids. }\end{array}$ \\
\hline 8. Soil microorganisms & $\begin{array}{l}\text { Add microbial grazer effects, effects on microorganisms during gut passage and faunal impact } \\
\text { on } \mathrm{C} \text { and } \mathrm{N} \text { coupling. See } 1-7 \text {. }\end{array}$ \\
\hline
\end{tabular}

* Recommendations refer to site-specific keystone groups of animals (dominating in terms of biomass or impact; see Fig. 2). Their prevalence is determined by climate, bedrock and land use (e.g. rodents or ants in deserts, earthworms in temperate grasslands, or microarthropods and enchytraeids in acidic northern forests).

Changes in climate (Blankinship et al., 2011), land use (Filser et al., 2002; Tsiafouli et al., 2015), resource availability and biotic interactions (de Vries et al., 2012; see Table 2) alter the distribution, community composition, activity and associated impact of soil animals on distribution and turnover rate of SOM (Wall et al., 2008) to the extent that underlying assumptions of SOM models may no longer be valid (Swift et al., 1998; Bardgett et al., 2013; Schmitz et al., 2014). Therefore, it is opportune to include approaches that have been developed during the past decades (Filser, 2002; Jiménez and Lal, 2006; Osler and Sommerkorn, 2007; Brussaard et al., 2007; Meysmann et al., 2006; Wall et al., 2008; Sanders et al., 2014). For instance, Lavelle et al. (2004) implemented earthworm activity in the CENTURY model. For this purpose, observations on long-term incubated earthworm casts and sieved control had been used as a reference. Afterwards, earthworm activity was simulated with CENTURY by replacing the active and slow soil $\mathrm{C}$ decomposition rates of the model with those obtained by calibration with the control soil. The simulations revealed a $10 \%$ loss of the slow $\mathrm{C}$ pool within 35 years compared to the original model without earthworms.

Without considering the role of animals, models are less accurate: in a field study spanning four countries from Sweden to Greece, soil food web properties were equally important as abiotic factors and predicted $\mathrm{C}$ and $\mathrm{N}$ cycling processes better than patterns of land use (de Vries et al., 2013). In their study, earthworms enhanced $\mathrm{CO}_{2}$ produc- tion, whereas Collembola and bacterivorous nematodes increased leaching of dissolved organic carbon. Mechanistic experiments confirm that earthworms have a detrimental effect on the greenhouse gas balance under nitrogen-rich conditions (Lubbers et al., 2013) and under no-till management (Lubbers et al., 2015). Inclusion of group-specific diversity of mesofauna in models of global-scale decomposition rates increased explained variance from 70 to $77 \%$ over abiotic factors alone (Wall et al., 2008). Also, García-Palacios et al. (2013) provide additional evidence on the argument that soil fauna activity is not merely a product of climate, soil properties and land use but an independent parameter. These examples indicate that the actors that play an important role in SOM dynamics should be considered in SOM models.

Model parameters are often measured in situ at relatively large spatial scales - at least compared with the size or activity range of most soil animals. As a result, the fauna effect is de facto included, although not appreciated (Swift et al., 1998). However, in many cases parameters are measured or extrapolated by combining in situ methods (e.g. monitoring of gas flux or litterbag experiments) and ex situ techniques such as laboratory experiments at controlled, highly simplified conditions. Especially the results of the latter may be sensitive to neglecting soil fauna. A relationship between animal activity and $\mathrm{C}$ turnover may vary with scale, for instance when soil properties or animal abundance differ at larger distance. However, as data are often insufficient, it will be context-dependent whether the inclusion of fauna is sensible 
or not (see Sect. 6). On the other hand, not taking explicitly into account the spatial heterogeneity created by soil fauna in field measurements might lead to substantial errors in calculating carbon budgets (Wu et al., 2013; Lopes de Gerenyu et al., 2015). It is thus crucial to develop sound (and biomespecific) strategies for combining in and ex situ measurements as parameters in more realistic SOM models.

Next to space, scale effects also apply to temporal patterns - which poses a great challenge for SOM modelling as most studies refer to rather short periods of time. We illustrate this by the comparatively well studied impact of invasive earthworms. The meta-analysis of Lubbers et al. (2013) suggests that the effect of earthworms on total soil organic carbon (SOC) contents is on average relatively small. In contrast, in certain situations earthworms can strongly affect greenhouse gas emission. These data were, however, mainly obtained in relatively short-term experiments. Over a period of months to years and even decades, earthworms can reduce $\mathrm{C}$ decomposition by physical protection of $\mathrm{C}$ in ageing casts ( $\mathrm{Six}$ et al., 2004; see Table 1).

Thus, long-lasting effects of invasive earthworms on the total SOC storage cannot be determined with certainty in short-term experiments, whereas field observations are rather controversial. For instance, Wironen and Moore (2006) reported ca. $30 \%$ increase in the total soil $\mathrm{C}$ storage in the earthworm-invaded sites of an old-growth beech-maple forest in Quebec. Other studies (e.g. Sackett et al., 2013; Resner et al., 2014) suggest a decrease in $C$ storage. Zhang et al. (2013) introduced the sequestration quotient concept to predict the overall effect of earthworms on the $\mathrm{C}$ balance in soils differing in fertility, but the question remains strongly understudied.

These well-documented examples of the impact of earthworms on soil $\mathrm{C}$ storage are related to invasive species. The presence of these species cannot be inferred directly from the climatic, soil and vegetation properties. The distributions of European invasive earthworms in North America, northern European forests or South Africa are largely driven by human activity. Often fishing (due to lost bait), imported plants or potting material of colonising farmers (Reinecke, 1983) is more important for these than habitat transformation - without human help earthworms are not active invaders (Stoscheck et al., 2012; Tiunov et al., 2006; Wironen and Moore, 2006). Thus, the presence of earthworms can be an environment-independent parameter of SOM dynamics.

Another fundamental issue in the large-scale approach is often neglected: when including the effects of the soil fauna implicitly, this assumes that the soil fauna will always have the same effects under the same conditions and hence that the soil fauna are essentially static. This assumption is increasingly unrealistic in a fast-changing world where both biodiversity and the climate are changing at accelerated paces, and where we are likely to witness major reorganisations of plant, animal and microbial communities. Therefore, explicit representation of the soil fauna, where possible, should increase the predictive ability of SOM models.

Given the fact that this issue had been raised decades back (see above), it appears somewhat astonishing that attempts to pursue it have not yet made any significant progress. We believe there are mainly three reasons for this: (a) missing information; (b) too much detail, irrespective of spatial scale; and (c) too little communication between empiricists and modellers. This is why we decided to bring into life a COST Action as an appropriate instrument to bridge these gaps. The next section gives an overview of it.

\section{Ways to proceed: COST Action ES 1406}

Based on the arguments compiled here, a COST Action entitled "Soil fauna - Key to Soil Organic Matter Dynamics and Modelling (KEYSOM)" was launched in March 2015 (http: //www.cost.eu/COST_Actions/essem/ES1406). An interdisciplinary consortium of soil biologists and biogeochemists, experimenters and modellers from 23 European countries plus the Russian Federation and the USA cooperates to implement soil fauna in improved SOM models as a basis for sustainable soil management. The main aim of KEYSOM is to test the hypothesis that the inclusion of soil fauna activities into SOM models will result in a better mechanistic understanding of SOM turnover and in more precise process descriptions and output predictions of soil processes, at least locally. A number of workshops address key challenges in experimentation and modelling of SOM and soil fauna and support research exchange and access to experimental data. Special attention is given to the education of young scientists. The action comprises four working groups (WGs) with the following topics:

1. knowledge gap analysis of SOM-soil fauna interactions;

2. potentials and limitations for inclusion of soil fauna effects in SOM modelling;

3. data assemblage and data sharing;

4. knowledge management and advocacy training.

After an intensive and enthusiastic workshop held in Osijek, Croatia, in October 2015, first activities included compilation of literature as well as setting up and keeping a website constantly up to date (http:// keysom.eu/). Meanwhile, short-term scientific missions for early-career scientists have been launched (http://keysom. eu/stsm/KEYSOM-STSMs-are-open-for-application), aiming for complementing the action's activities. The second workshop was held in Prague in April 2016.

Next to a first compilation of knowledge gaps in this article, present activities of KEYSOM involve

- a literature review on biome-specific effects of soil fauna impact on SOM turnover; 
- a literature review on the impact of soil fauna other than earthworms on SOM turnover;

- a compilation of the potentials and limitations of existing SOM models;

- the development of a simple SOM model that also explicitly incorporates soil animals and associated processes in it, based on the current state of knowledge exchange between empiricists and modellers within KEYSOM;

- the preparation of a common Europe-wide field study into the impact of soil fauna composition and abundance on SOM breakdown, distribution and aggregate formation, which will start in autumn 2016;

- the preparation of a summer school, to be held in early October 2016 in Coimbra, Portugal.

Figure 3 illustrates the present state of our interdisciplinary discussions, providing a roadmap for how SOM models could be supplemented with the effects of soil fauna. In the first phase, empiricists (Fig. 3a) and modellers (Fig. 3b) work in parallel. Mutual exchange between these groups is guaranteed by the regular workshop meetings such as in Osijek and Prague.

The stepwise approach functions like a decision tree, with various feedback loops and options at every step if and how known effects of soil fauna could be implemented into SOM. It also identifies under which circumstances additional research (literature review or experimental studies) needs to be initiated before proceeding further. Like many existing models, the new model should also have a modular structure so that different modules can be used and combined according to the respective biome- and scale-specific scenario (Fig. 3c). It can also be seen that we do not aim to include every detail everywhere: in some situations (Fig. 3a) the impact of soil fauna on SOM dynamics might be too small (or existing information too scanty) to be included, and not all input parameters will be feasible or relevant at each scale (miniature in Fig. 3c). This keeps the model manageable, and also flexible enough to allow for more precise predictions in critical scenarios, like in the case of earthworm invasions outlined in Sect. 5. We generally think that focusing on such critical scenarios (analogous to, for example, global biodiversity hotspots) is a crucial precondition for well-informed management decisions, one of the final aims of KEYSOM.

As an example, box no. 1 in Fig. 3a represents the first literature review in the above list. Depending on the outcome, for each biome a decision will be made if the impact of fauna on SOM turnover is unknown, relevant or low. In the first case, more research is needed; in the last case, the faunal effect can be ignored. Depending on the outcome of additional research, the knowledge base will be improved and the decision between ignoring and proceeding further can be made anew. If a strong effect is expected, the next question (box no. 2 in Fig. 3a) will be addressed and so forth.

Once the procedure in Fig. 3a has reached box no. 4, intensive exchange with modellers (Fig. 3b) is mandatory to identify the relevant model parameters and the type of functional relationship (box 5). Mechanistic aspects (such as chemical transformation in the gut, physical protection within aggregates or impact on hydraulic soil properties via digging) are of prime importance here as each of these examples may have different effects on $\mathrm{C}$ turnover. Effects of fauna abundance or biomass (in comparison to presence-absence) on the shape of the function will be addressed as well. Note, however, that to date necessary data for such an approach appear to be limited (García-Palacios et al., 2013). In the meantime, the modellers will have developed a basic model structure and compared it with the structures of existing SOM models concerning potentials and limitations for including fauna effects (Fig. 3b).

The second phase (Fig. 3c) starts with the practical tests of the collected model parameters (boxes 6 and 7), using data that have been compiled by then by WG 3, allowing for selecting the best model (box 8). At this point, spatial scale comes into play, which is likely to be the most critical issue: as we have also seen while preparing this article, existing data on the impact of soil fauna on SOM turnover are highly diverse, from short-term and often highly artificial experiments at controlled conditions to large-scale correlative field studies in all kinds of different environments (and with a strong bias with respect to certain biomes). The type of relationship between faunal abundance and SOM turnover will in most cases vary with scale. If data for different scales are not available (box 9), further research is needed. In the second case, one can proceed with boxes 10 and 11 .

Importantly, the idea is not to include the fauna in every situation everywhere. Rather, we aim at identifying critical hotspots and scenarios (see above) where faunal activities play a crucial role in SOM turnover, as demonstrated in Sect. 5. Due to the above-mentioned differences between biomes and scale effects, these scenarios will be biome- and scale-specific. An example is shown in the lower left corner of Fig. 3c. For Biome A, hydraulic properties have been identified to be crucial for SOM dynamics. Thus, data are needed on animals that affect these, such as digging earthworms or rodents. Instead, the analyses for Biome B have revealed aggregate structure and microorganisms being most relevant requiring respective data at the small scale. On a larger scale such data for microorganisms might not be available, which implies proceeding with aggregate structure alone.

Overall, the whole approach requires a modular model structure, allowing for using different models according to the respective situation and data availability. This is what WG 2 is currently developing. Certainly all the research outlined here cannot be done within one single COST Action. Based on the outcome of our work, we hope to come up with a more detailed roadmap for how to further proceed to improve SOM modelling. This roadmap, together with what 
could be achieved with the limited resources of KEYSOM, will provide information material, decision tools and management options for decision makers and politicians (WG 4).

\section{Conclusions and outlook}

Understanding and modelling SOM is essential for managing the greenhouse gas balance of the soil, for land restoration from desertification, for sustaining food production and for the conservation of above- and below-ground biodiversity and associated ecosystem services (Nielsen et al., 2015). Soil animal abundance, biodiversity, species traits and interactions are crucial for SOM turnover (Chauvel et al., 1999; Bohlen et al., 2004; Wardle et al., 2004; Wall et al., 2008; Uvarov, 2009). In Table 2 we give recommendations on how the known impact of soil fauna on SOM turnover could be used for improving carbon models. Due to the pronounced differences with respect to climate, soil and land use outlined above, it is important that these recommendations are considered region- and scale-specific, taking into account the key players and their specific activities in the respective area.

Author contributions. Juliane Filser wrote the article, prepared Figs. 1 and 3 and the tables and compiled the contributions from all co-authors, who are listed according to their quantitative and qualitative impact on the manuscript, except for Juan José Jiménez, who was placed last as he is the chair of COST Action ES 1406 (KEYSOM). Lijbert Brussaard suggested including Fig. 2.

Acknowledgements. The two anonymous referees and O. Schmitz are acknowledged for their critical comments, which significantly contributed to the revision of the original manuscript. We thank Antje Mathews for compiling the references and editing the manuscript. Many thanks to Karin Nitsch for linguistic proofreading. Oxford University Press and Wiley and Sons are acknowledged for the permission to include Fig. 2. This paper is a contribution to the COST Action ES1406 (KEYSOM) lead by the first and last author. A lot of the writing was inspired by the lively discussions within the workshop meetings of KEYSOM - thanks to all contributors! We thank the COST Association for financially supporting collaboration and networking activities across Europe.

The article processing charges for this open-access publication were covered by the University of Bremen.

Edited by: M. Muñoz-Rojas

Reviewed by: O. Schmitz and two anonymous referees

\section{References}

A'Bear, A. D., Boddy, L., and Jones, T. H.: Impacts of elevated temperature on the growth and functioning of decomposer fungi are influenced by grazing collembola, Global Change Biol., 18, 1823-1832, 2012.

Ameloot, N., Graber, E. R., Verheijen, F. G., and De Neve, S.: Interactions between biochar stability and soil organisms: review and research needs, Eur. J. Soil Sci., 64, 379-390, 2013.

Amézketa, E.: Soil aggregate stability: a review, J. Sustain. Agricult., 14, 83-151, 1999.

Andriuzzi, W. S., Pulleman, M. M., Schmidt, O., Faber, J. H., and Brussaard, L.: Anecic earthworms (Lumbricus terrestris) alleviate negative effects of extreme rainfall events on soil and plants in field mesocosms, Plant Soil, 397, 103-113, doi:10.1007/s11104015-2604-4, 2015.

Arai, M., Tayasu, I., Komatsuzaki, M., Uchida, M., Shibata, Y., and Kaneko, N.: Changes in soil aggregate carbon dynamics under no-tillage with respect to earthworm biomass revealed by radiocarbon analysis, Soil Till. Res., 126, 42-49, 2013.

Arnone, J. A. and Zaller, J. G.: Earthworm effects on native grassland root system dynamics under natural and increased rainfall, Front. Plant Sci., 5, 1-8, 2014.

Ayuke, F. O., Brussaard, L., Vanlauwe, B., Six, J., Lelei, D. K., Kibunja, C. N., and Pulleman, M. M.: Soil fertility management: Impacts on soil macrofauna, soil aggregation and soil organic matter allocation, Appl. Soil Ecol., 48, 53-62, 2011.

Ballantyne, A. P., Alden, C. B., Miller, J. B., Tans, P. P., and White, J. W. C.: Increase in observed net carbon dioxide uptake by land and oceans during the past 50 years, Nature, 488, 70-72, 2012.

Bardgett, R. D., Manning, P., Morrien, E., and de Vries, F. T.: Hierarchical responses of plant-soil interactions to climate change: consequences for the global carbon cycle, J. Ecol., 101, 334-343, 2013.

Blanchart, E., Lavelle, P., Bruadeau, E., Le Bissonnais, Y., and Valentin, C.: Regulation of soil structure by geophagous earthworm activities in humid savannas of Côte d'Ivoire, Soil Biol. Biochem., 29, 431-439, 1997.

Blankinship, J. C., Niklaus, P. A., and Hungate, B. A.: A metaanalysis of responses of soil biota to global change, Oecologia, 165, 553-565, 2011.

Blume, H.-P., Brümmer, G. W., Horn, R., Kandeler, E., KögelKnabner, I., Kretzschmar, R., Stahr, K., and Wilke, B. M.: Scheffer/Schachtschabel: Lehrbuch der Bodenkunde, Springer, Heidelberg, 2009.

Bohlen, P. J., Groffmann, P. M., Fahey, T. J., Fisk, M. C., Suárez, E., Pelletier, D. M., and Fahey, R. T.: Ecosystem Consequences of Exotic Earthworm Invasion of North Temperate Forests, Ecosystems, 7, 1-12, 2004.

Bolduan, R. and Zehe, E.: Abbau von Isoproturon in RegenwurmMakroporen und in der Unterbodenmatrix - Eine Feldstudie, J. Plant Nutr. Soil Sci., 169, 87-94, doi:10.1002/jpln.200521754, 2006.

Bonkowski, M., Villenave, C., and Griffiths, B.: Rhizosphere fauna: the functional and structural diversity of intimate interactions of soil fauna with plant roots, Plant Soil, 321, 213-233, 2009.

Bossuyt, H., Six, J., and Hendrix, P. F.: Protection of soil carbon by microaggregates within earthworm casts, Soil Biol. Biochem., 37, 251-258, 2005. 
Bossuyt, H., Six, J., and Hendrix, P. F.: Interactive effects of functionally different earthworm species on aggregation and incorporation and decomposition of newly added residue carbon, Geoderma, 130, 14-25, 2006.

Bottinelli, N., Jouquet, P., Capowiez, Y., Podwojewski, P., Grimaldi, M., and Peng, X.: Why is the influence of soil macrofauna on soil structure only considered by soil ecologists?, Soil Till. Res., 146, 118-124, 2015.

Briones, M. J. I.: Soil fauna and soil functions: a jigsaw puzzle, Front. Environ. Sci., 2, 1-22, 2014.

Brown, G. G.: How do earthworms affect microfloral and faunal community diversity?, Plant Soil, 170, 209-231, 1995.

Brown, G. G., Edwards, C. A., and Brussaard, L.: How Earthworms Affect Plant Growth: Burrowing into the Mechanisms, in: Earthworm Ecology, 2nd Edn., CRC Press, Boca Raton, 13-49, 1994.

Brussaard, L. and Juma, N. G.: Organisms and humus in soils, in: Humic substances in terrestrial ecosystems, edited by: Piccolo, A., Elsevier, Amsterdam, 329-359, 1996.

Brussaard, L., Pulleman, M. M., Ouédraogo, E., Mando, A., and Six, J.: Soil fauna and soil function in the fabric of the food web, Pedobiologia, 50, 447-462, 2007.

Brussaard, L., Aanen, D. K., Briones, M. J. I., Decaëns, T., De Deyn, G. B., Fayle, T. M., James, S. W., and Nobre, T.: Biogeography and Phylogenetic Community Structure of Soil Invertebrate Ecosystem Engineers: Global to Local Patterns, Implications for Ecosystem Functioning and Services and Global Environmental Change Impacts, Soil Ecol. Ecosyst. Serv., 201-232, 2012.

Chauvel, A., Grimaldi, M., Barros, E., Blanchart, E., Deshardins, T., and Lavelle, P.: Pasture damage by an Amazonian earthworm, Nature, 398, 32-33, 1999.

Chmura, G. L., Anisfeld, S. C., Cahoon, D. R., and Lynch, J. C.: Global carbon sequestration in tidal, saline wetland soils, Global Biogeochem. Cy., 17, 1-12, 2003.

Clemmensen, K. E., Bahr, A., Ovaskainen,, O., Dahlberg, A., Ekblad, A., Wallander, H., Stenlid, J., Finlay, R. D., Wardle, D. A., and Lindahl, B. D.: Roots and Associated Fungi Drive Long-Term Carbon Sequestration in Boreal Forest, Science, 339, 1615-1618, 2013.

Corréa, M. M., Silva, P. S. D., Wirth, R., Tabarelli, M., and Leal, I. R.: How leaf-cutting ants impact forests: drastic nest eVects on light environment and plant assemblages, Oecologia, 162, 103$115,2010$.

Coulis, M., Hättenschwiler, S., Rapior, S., and Coq, S.: The fate of condensed tannins during litter consumption by soil animals, Soil Biol. Biochem., 41, 2573-2578, 2009.

Crowther, T. W., Boddy, L., and Jones, T. H.: Outcomes of fungal interactions are determined by soil invertebrate grazers, Ecol. Lett., 14, 1134-1142, 2011.

David, J. F.: The role of litter-feeding macroarthropods in decomposition processes: A reappraisal of common views, Soil Biol. Biochem., 76, 109-118, 2014.

Davidson, E. A. and Janssens, I. A.: Temperature sensitivity of soil carbon decomposition and feedbacks to climate change, Nature, 440, 165-173, 2006.

De Deyn, G. B., Cornelissen, J. H. C., and Bardgett, R. D.: Plant functional traits and soil carbon sequestration in contrasting biomes, Ecol. Lett., 11, 516-531, 2008. de Vries, F. T., Liiri, M. E., Bjørnlund, L., Bowker, M. A, Christensen, S., Setälä, H. M., and Bardgett, R. D.: Land use alters the resistance and resilience of soil food webs to drought, Nat. Clim. Change, 2, 276-280, 2012.

de Vries, F. T., Thébault, E., Liiri, M., Birkhofer, K., Tsiafouli, M. A., Bjørnlund, L, Bracht Jørgensen, H., Brady, M. V., Christensen, S., De Ruiter, P., d'Hertefeld, T., Frouz, J., Hedlund, K., Hemerik, L., Hol, W. H. G., Hotes, S., Mortimer, S. R., Setälä, H., Sgardelis, S. P., Uteseny, K., Van der Putten, W. H., Wolters, V., and Bardgett, R. D.: Soil food web properties explain ecosystem services across European land use systems, P. Natl. Acad. Sci. USA, 110, 14296-14301, 2013.

Dickinson, C. H. and Pugh, G. J. F.: Biology of plant litter decomposition, Vol. 2, Academic Press, London, New York, 2012.

Dorn, R. I.: Ants as a powerful biotic agent of olivine and plagioclase dissolution, Geology, 42, 771-774, 2014.

Eckmeier, E., Gerlach, R., Skjemstad, J. O., Ehrmann, O., and Schmidt, M. W. I.: Minor changes in soil organic carbon and charcoal concentrations detected in a temperate deciduous forest a year after an experimental slash-and-burn, Biogeosciences, 4, 377-383, doi:10.5194/bg-4-377-2007, 2007.

Edwards, C. A. and Bohlen, P.: Biology and ecology of earthworms, Chapman \& Hall, London, 1-426, 1996.

Edwards, C. A. and Fletcher, K. E.: Interactions between Earthworms and Micro-organisms in Organic-matter Breakdown, Agr. Ecosyst. Environ., 24, 235-247, 1988.

Edwards, W. M., Shipitalo, M. J., Traina, S. J., Edwards, C. A., and Owens, L. B.: Role of lumbrlcus terrestris (1.) burrows on quality of infiltrating, Soil Biol. Biochem., 24, 1555-1561, 1992.

Eisenhauer, N., Partsch, S., Parkinson, D., and Scheu, S.: Invasion of a deciduous forest by earthworms: Changes in soil chemistry, microflora, microarthropods and vegetation, Soil Biol. Biochem., 39, 1099-1110, 2007.

Ettema, C. H. and Wardle, D. A.: Spatial soil ecology, Trends Ecol. Evol., 17, 177-183, 2002.

Filser, J.: The role of Collembola in carbon and nitrogen cycling in soil, Pedobiologia, 46, 234-245, 2002.

Filser, J. and Prasse, R.: A glance on the fauna of Nizzana, in: A Sandy Ecosystem at the Desert Fringe, edited by: Yair, A., Veste, M., and Breckle, S.-W., Springer, Heidelberg, 125-147, 2008.

Filser, J., Fromm, H., Nagel, R., and Winter, K.: Effects of previous intensive agricultural management on microorganisms and the biodiversity of soil fauna, Plant Soil, 170, 123-129, 1995.

Filser, J., Mebes, K.-H., Winter, K., Lang, A., and Kampichler, C.: Long-term dynamics and interrelationships of soil Collembola and microorganisms in an arable landscape following land use change, Geoderma, 105, 201-221, 2002.

Finzi, A. C., Abramov, R. Z., Spiller, K. S., Brzostek, E. R., Darby, B. A., Kramer, M. A., and Phillips, R. P.: Rhizosphere processes are quantitatively important components of terrestrial carbon and nutrient cycles, Global Change Biol., 21, 2082-2094, 2015.

Flegel, M., Schrader, S., and Zhang, H.: Influence of food quality on the physical and chemical properties of detritivorous earthworm casts, Appl. Soil Ecol., 9, 263-269, 1998.

Fox, O., Vetter, S., Ekschmitt, K., and Wolters, V.: Soil fauna modifies the recalcitrance-persistence relationship of soil carbon pools, Soil Biol. Biochem., 38, 1353-1363, 2006.

Frelich, L. E., Hale, C. M., Scheu, S., Holdsworth, A. R., Heneghan, L., Bohlen, P. J., and Reich, P. B.: Earthworm invasion into pre- 
viously earthworm-free temperate and boreal forests, Biol. Invasions, 8, 1235-1245, 2006.

Frouz, J., Li, X., Brune, A., Pizl, V., and Abakumov, E. V.: Effect of Soil Invertebrates on the Formation of Humic Substances under Laboratory Conditions, Euras. Soil Sci., 44, 893-896, 2011.

Frouz, J., Livecková, M., Albrechtová, J., Chronaková, A., Cajthaml, T., Pizl, V., Hánel, L., Stary, J., Baldrian, P., Lhotáková, Z., Simácková, H., and Cepáková, S.: Is the effect of trees on soil properties mediated by soil fauna? A case study from postmining sites, Forest Ecol. Manage., 309, 87-95, 2013.

Frouz, J., Roubicková, A., Hedenec, P., and Tajovský, K.: Do soil fauna really hasten litter decomposition? A meta-analysis of enclosure studies, Eur. J. Soil Biol., 68, 18-24, 2015 a.

Frouz, J., Spaldonová, A., Lhotáková, Z., and Cajthaml, T.: Major mechanisms contributing to the macrofauna-mediated slow down of litter decomposition, Soil Biology Biochem., 91, 23-31, 2015b.

García-Palacios, P., Maestre, F. T., Kattge, J., and Wall, D. H.: Climate and litter quality differently modulate the effects of soil fauna on litter decomposition across biomes, Ecol. Lett., 16, 1045-1053, 2013.

Guéi, A. M., Baidai, Y., Tondoh, J. E., and Huising, J.: Functional attributes: Compacting vs decompacting earthworms and influence on soil structure, Curr. Zool., 58, 556-565, 2012.

Guggenberger, G., Zech, W., and Thomas, R. J.: Lignin and carbohydrate alteration in particle-size separates of an oxisol under tropical pastures following native savanna, Soil Biol. Biochem., 27, 1629-1638, 1995.

Guggenberger, G., Thomas, R. J., and Zech, W.: Soil organic matter within earthworm casts of an anecic-endogeic tropical pasture community, Colombia, Appl. Soil Ecol., 3, 263-274, 1996.

Hedde, M., Lavelle, P., Joffre, R., Jiménez, J. J., and Decaens, T.: Specific functional signature in soil macro-invertebrate biostructures, Funct. Ecol., 19, 785-793, 2005.

Hoogerkamp, M., Rogaar, H., and Eijsackers, H. J. P.: Effect of earthworms on grassland on recently reclaimed polder soils in the Netherlands, in: Earthworm Ecology, edited by: Satchell, J. E., Chapman and Hall, London, New York, 85-105, 1983.

Ji, R. and Brune, A.: Nitrogen mineralization, ammonia accumulation, and emission of gaseous $\mathrm{NH}_{3}$ by soil-feeding termites, Biogeochemistry, 78, 267-283, 2006.

Jiménez, J. J. and Lal, R.: Mechanisms of C Sequestration in Soils of Latin America, Crit. Rev. Plant Sci., 25, 337-365, 2006.

Jiménez, J. J., Decaëns, T., and Rossi, J. P.: Soil environmental heterogeneity allows spatial co-occurrence of competitor earthworm species in a gallery forest of the Colombian "Llanos", Oikos, 121, 915-926, doi:10.1111/j.1600-0706.2012.20428.x, 2012.

Johnson, D., Krsek, M., Wellington, E. M. H., Stott, A. W., Cole, L., Bardgett, R. D., Read, D. J., and Leake, J. R.: Soil Invertebrates Disrupt Carbon Flow Through Fungal Networks, Science, 309, 1047, 2005.

Jouquet, P., Dauber, J., Lagerlöf, J., Lavelle, P., and Lepage, M.: Soil invertebrates as ecosystem engineers: Intended and accidental effects on soil and feedback loops, Appl. Soil Ecol., 32, 153-164, 2006.

Kanters, C., Anderson, I. C., and Johnson, D.: Chewing up the Wood-Wide Web: Selective Grazing on Ectomycorrhizal Fungi by Collembola, Forests, 6, 2560-2570, 2015.
Kubiena, W. L.: Soils of Europe, 1st Edn. (December 1953), Thomas Murby \& Co., London, 1-318, 1953.

Lavelle, P.: Les vers de terre de la savane de Lamto, Côte d'Ivoire: peuplements, populations et fonctions dans l'écosysteme, Publ. Lab. Zool. E.N.S., Ecole Normale Supérieure de Paris, Paris, 1301, 1978.

Lavelle, P.: Earthworm activities and the soil system, Biol. Fert. Soils, 6, 237-251, 1988.

Lavelle, P. and Martin, A.: Small-Scale and Large-Scale Effects of Endogenic Earthworms on Soil Organic-Matter Dynamics in Soils of the Humid Tropics, Soil Biol. Biochem., 24, 1491-1498, 1992.

Lavelle, P. and Spain, A. V.: Soil Ecology, 2nd Edn., Kluwer Scientific Publications, Amsterdam, 2006.

Lavelle, P., Pashanasi, B., Charpentier, F., Gilot, C., Rossi, J.-P., Derouard, L., André, J., Ponge, J.-F., and Bernier, N.: Large-scale effects of earthworms on soil organic matter and nutrient dynamics, in: Earthworm Ecology, edited by: Edwards, C. A., St. Lucies Press, Boca Raton, 103-122, 1998.

Lavelle, P., Charpentier, F., Villenave, C., Rossi, J.-P., Derouard, L., Pashanasi, B., André, J., Ponge, J.-F., and Bernier, N.: Effects of Earthworms on Soil Organic Matter and Nutrient Dynamics at a Landscape Scale over Decades, in: Earthworm Ecology, edited by: Edwards, C. A., CRC Press, Boca Raton, 145-160, 2004.

Lee, K. E.: Earthworms: their ecology and relationships with soils and land use, Academic Press, Sydney, 1-654, 1985.

Lehmann, J. and Kleber, M.: The contentious nature of soil organic matter, Nature, 528, 60-68, doi:10.1038/nature16069, 2015.

Li, X. and Brune, A.: Transformation and mineralization of soil organic nitrogen by the humivorous larva of Pachnoda ephippiata (Coleoptera: Scarabaeidae), Plant Soil, 301, 233-244, 2007.

Li, X., Ji, R., Schäffer, A., and Brune, A.: Mobilization of soil phosphorus during passage through the gut of larvae of Pachnoda ephippiata (Coleoptera: Scarabaeidae), Plant Soil, 288, 263-270, 2006.

Liebeke, M., Strittmatter, N., Fearn, S., Morgan, J., Kille, P., Fuchser, J., Wallis, D., Palchykov, V., Robertson, J., Lahive, E., Spurgeon, D. J., McPhail, D., Takáts, Z., and Bundy, J. G.: Unique metabolites protect earthworms against plant polyphenols, Nat. Commun., 6, 1-7, 2015.

Lindén, A., Heinonsalo, J., Buchmann, N., Oinonen, M., Sonninen, E., Hilasvuori, E., and Pumpanen, J.: Contrasting effects of increased carbon input on boreal SOM decomposition with and without presence of living root system of Pinus sylvestris L., Plant Soil, 377, 145-158, 2014.

Lopes de Gerenyu, V. O., Anichkin, A. E., Avilov, V. K., Kuznetsov, A. N., and Kurganova, I. N.: Termites as a Factor of Spatial Differentiation of $\mathrm{CO}_{2}$ Fluxes from the Soils of Monsoon Tropical Forests in Southern Vietnam, Euras. Soil Sci., 48, 208-217, 2015.

Lubbers, I. M., van Groenigen, K. J., Fonte, S. J., Brussaard, L., Six, J., and van Groenigen, J. W.: Greenhouse-gas emissions from soils increased by earthworms, Nat. Clim. Change, 3, 187-194, 2013.

Lubbers, I. M., van Groenigen, K. J., Brussaard, L., and van Groenigen, J. W.: Reduced greenhouse gas mitigation potential of no-tillage soils through earthworm activity, Nature, 5, 13787,doi:10.1038/srep13787, 2015. 
Luo, Y., Keenan, T. F., and Smith, M.: Predictability of the terrestrial carbon cycle, Global Change Biol., 21, 1737-1751, 2015.

Malmström, A.: Life-history traits predict recovery patterns in Collembola' species after fire: A 10 year study, Appl. Soil Ecol., 56, 35-42, 2012.

Marashi, A. R. A. and Scullion, J.: Earthworm casts form stable aggregates in physically degraded soils, Biol. Fert. Soils, 37, 375380, 2003.

Martin, A. and Marinissen, J. C. Y.: Biological and physicochemical processes in excrements of soil animals, Geoderma, 56, 331-347, 1993.

Meysmann, F. J. R., Middelburg, J., and Heip, C. H. R.: Bioturbation: a fresh look at Darwin's last idea, Trends Ecol. Evol., 21, 688-695, 2006.

Nielsen, U. N., Wall, D. H., and Six, J.: Soil Biodiversity and the Environment, Annu. Rev. Environ. Resour., 40, 63-90, 2015.

Oades, J. M.: The role of biology in the formation, stabilization and degradation of soil structure, Geoderma, 56, 377-400, 1993.

Osler, G. H. R. and Sommerkorn, M.: Toward a Complete Soil C and N Cycle: Incorporating the Soil Fauna, Ecology, 88, 16111621, 2007.

Persson, T.: Role of soil animals in $\mathrm{C}$ and $\mathrm{N}$ mineralisation, in: Ecology of arable land, edited by: Clarholm, M. and Bergström, L., Kluwer Academic Publisher, Dordrecht, the Netherlands, 185189, 1989.

Pollierer, M., Langel, R., Körner, C., Maraun, M., and Scheu, S.: The underestimated importance of belowground carbon input for forest soil animal food webs, Ecol. Lett., 10, 729-736, 2007.

Reinecke, A. J.: The ecology of earthworms in Southern Africa, in: Earthworm ecology, from Darwin to Vermiculture, edited by: Satchell, J. A., Chapman and Hall, London, 195-207, 1983.

Resner, K., Yoo, K., Sebestyen, S. D., Aufdenkampe, A., Hale, C., Lyttle, A., and Blum, A.: Invasive Earthworms Deplete Key Soil Inorganic Nutrients $(\mathrm{Ca}, \mathrm{Mg}, \mathrm{K}$, and $\mathrm{P})$ in a Northern Hardwood Forest, Ecosystems, 18, 89-102, 2014.

Sackett, T. E., Smith, S. M., and Basiliko, N.: Soil Biology \& Biochemistry Indirect and direct effects of exotic earthworms on soil nutrient and carbon pools in North American temperate forests, Soil Biol. Biochem., 57, 459-467, 2013.

Sanders, D., Jones, C. G., Thébault, E., Bouma, T. J., van der Heide, T., van Belzen, J., and Barot, S.: Integrating ecosystem engineering and food webs, Oikos, 123, 513-524, 2014.

Scheu, S., Schlitt, N., Tiunov, A. V., Newington, J. E., and Jones, T. H.: Effects of the Presence and Community Composition of Earthworms on Microbial Community Functioning, Oecologia, 133, 254-260, 2002.

Schmidt, M. W., Torn, M. S., Abiven, S., Dittmar, T., Guggenberger, G., Janssens, I. A., Kleber, M., Kögel-Knabner, I., Lehmann, J., Manning, D. A. C., Nannipieri, P., Rasse, D. P., Weiner, S., and Trumbore, S. E.: Persistence of soil organic matter as an ecosystem property, Nature, 478, 49-56, 2011.

Schmitz, O. J., Raymond, P. A., Estes, J. A., Kurz, W. A., Holtgrieve, G. W., Ritchie, M. E., Schindler, D. E., Spivak, A. C., Wilson, R. W., Bradford, M. A., Christensen, V., Deegan, L., Smetacek, V., Vanni, M. J., and Wilmers, C. C.: Animating the Carbon Cycle, Ecosystems, 17, 344-359, 2014.

Schrader, S. and Zhang, H.: Earthworm Casting: Stabilization or Destabilization of Soil Structure?, Soil Biol. Biochem., 29, 469475, 1997.
Shipitalo, M. J. and Protz, R.: Factors influencing the dispersibility of clay in worm casts, Soil Sci. Soc. Am. J., 52, 764-769, doi:10.2136/sssaj1988.03615995005200030030x, 1988.

Šimanský, V. and Kováčik, P.: Carbon Sequestration and its Dynamics in water-stable Aggregates, Agriculture, 60, 1-9, 2014.

Six, J., Bossuyt, H., Degryze, S., and Denef, K.: A history of research on the link between (micro)aggregates, soil biota, and soil organic matter dynamics, Soil Till. Res., 79, 7-31, 2004.

Stoscheck, L. M., Sherman, R. E., Suarez, E. R. and Fahey, T. J.: Exotic earthworm distributions did not expand over a decade in a hardwood forest in New York state, Appl. Soil Ecol., 62, 124 130, 2012.

Swift, M. J., Heal, O. W., and Anderson, J. M.: Decomposition in terrestrial ecosystems, Blackwell Scientific Publications, Oxford, 1-372, 1979.

Swift, M. J., Andrén, O., Brussaard, L., Briones, M., Couteaux, M.-M., Ekschmitt, K., Kjoller, A., Loiseau, P., and Smith, P.: Global change, soil biodiversity, and nitrogen cycling in terrestrial ecosystems: three case studies, Global Change Biol., 4, 729743, 1998.

Tarnocai, C., Canadell, J. G., Schuur, E. A. G., Kuhry, P., Mazhitova, G., and Zimov, S.: Soil organic carbon pools in the northern circumpolar permafrost region, Global Biogeochem. Cy., 23, GB2023, doi:10.1029/2008GB003327, 2009.

Tisdall, J. M. and Oades, J. M.: Organic matter and water-stable aggregates in soils, J. Soil Sci., 33, 141-163, 1982.

Tiunov, A. V., Hale, C. M., Holdsworth, A. R., and VsevolodovaPerel, T. S.: Invasion patterns of Lumbricidae into the previously earthworm-free areas of northeastern Europe and the western Great Lakes region of North America, Biol. Invasions, 8, 1223 1234, 2006.

Topoliantz, S. and Ponge, J.-F.: Burrowing activity of the geophagous earthworm Pontoscolex corethrurus (Oligochaeta: Glossoscolecidae) in the presence of charcoal, Appl. Soil Ecol., 23, 267-271, 2003.

Topoliantz, S., Ponge, J.-F., and Lavelle, P.: Humus components and biogenic structures under tropical slash-and-burn agriculture, Eur. J. Soil Sci., 57, 269-278, 2006.

Tsiafouli, M. A., Thébault, E., Sgardelis, S. P., De Ruiter, P. C., Van der Putten, W. H., Birkhofer, K., Hemerik, L., de Vries, F. T., Bardgett, R. D., Brady, M. V., Bjørnlund, L., Bracht Jørgensen, H., Christensen, S., d'Hertefeld, T., Hotes, S., Hol, W. H. G., Frouz, J., Liiri, M., Mortimer, S. R., Setälä, H., Tzanopoulos, J., Uteseny, K., Pizl, V., Stary, J., Wolters, V., and Hedlund, K.: Intensive agriculture reduces soil biodiversity across Europe, Global Change Biol., 21, 973-985, 2015.

Ulyshen, M. D.: Wood decomposition as influenced by invertebrates, Biol. Rev., 91, 70-85, 2016.

Uvarov, A. V.: Energetical evaluation of the role of soil invertebrates in the process of plant remains decomposition, in: Soil Fauna and Soil Fertility, Nauka Sci. Publ., edited by: Striganova, B. R., Proceedings of the 9th International Colloquium on Soil Zoology, August 1985, Moscow, 143-150, 1987.

Uvarov, A. V.: Inter- and intraspecific interactions in lumbricid earthworms: Their role for earthworm performance and ecosystem functioning, Pedobiologia, 53, 1-27, 2009.

van de Westeringh, W.: Deterioration of soil structure in worm free orchards, Pedobiologia, 12, 6-15, 1972. 
van Geffen, K. G., Berg, M. P., and Aerts, R.: Potential macrodetritivore range expansion into the subarctic stimulates litter decomposition: a new positive feedback mechanism to climate change?, Oecologia, 167, 1163-1175, 2011.

Wall, D. H., Bradford, M. A., St. John, M. G., Trofymow, J. A., Behan-Pelletier, V., Bignell, D. E., Dangerfield, J. M., Parton, W. J., Rusek, J., Voigt, W., Wolters, V., Gardel, H. Z., Ayuke, F. O., Bashford, R., Beljakova, O. I., Bohlen, P. J., Brauman, A., Flemming, S., Henschel, J. R., Johnson, D. L., Jones, T. H., Kovarova, M., Kranabetter, J. M., Kutny, L., Lin, K.-C., Maryati, M., Masse, D., Pokarzhevskii, A., Rahman, H., Sabará, M. G., Salamon, J.A., Swift, M. J., Varela, A., Vasconcelos, H. L., White, D., and Zou, X.: Global decomposition experiment shows soil animal impacts on decomposition are climate-dependent, Global Change Biol., 14, 2661-2677, 2008.

Wang, J., Xiong, Z., and Kuzyakov, Y.: Biochar stability in soil: meta-analysis of decomposition and priming effects, GCB Bioenergy, 8, 512-523, 2016.

Wardle, D. A., Bardgett, R. D., Klironomos, J. N., Setälä, H., Van der Putten, W. H., and Wall, D. H.: Ecological Linkages Between Aboveground and Belowground Biota, Science, 304, 1629-1633, 2004.
Wilkinson, M. T., Richards, P. J., and Humphreys, G. S.: Breaking ground: Pedological, geological, and ecological implications of soil bioturbation, Earth-Sci. Rev., 97, 257-272, 2009.

Wironen, M. and Moore, T. R.: Exotic earthworm invasion increases soil carbon and nitrogen in an old-growth forest in southern Quebec, Can. J. Forest Res., 36, 845-854, 2006.

Wu, H., Lu, X., Wu, D., Song, L., Yan, X., and Liu, J.: Ant mounds alter spatial and temporal patterns of $\mathrm{CO}_{2}, \mathrm{CH}_{4}$ and $\mathrm{N}_{2} \mathrm{O}$ emissions from a marsh soil, Soil Biol. Biochem., 57, 884-889, 2013.

Zaitsev, A. S., Gongalsky, K. B., Persson, T., and Bengtsson, J.: Connectivity of litter islands remaining after a fire and unburnt forestdetermines the recovery of soil fauna, Appl. Soil Ecol., 83, 101-108, 2014.

Zangerlé, A., Hissler, C., Blouin, M., and Lavelle, P.: Near infrared spectroscopy (NIRS) to estimate earthworm cast age, Soil Biol. Biochem., 70, 47-53, 2014.

Zhang, W., Hendrix, P. F., Dame, L. E., Burke, R. A., Wu, J., Neher, D. A., Li, J., Shao, Y., and Fu, S.: Earthworms facilitate carbon sequestration through unequal amplification of carbon stabilization compared with mineralization, Nat. Commun., 4, 2576, doi:10.1038/ncomms3576, 2013. 